\title{
COUMARINS FROM THE ROOTS OF Platytaenia dasycarpa
}

$$
\text { G. A. Zhukov, A. P. Prokopenko, }
$$
and M. G. Pimenov

UDC 547.588

In ethanolic extracts from the roots of Platytaenia dasycarpa (Regl. et Schmalh.) Korov. collected in the valley of the $R$. Chichkan (Kirghiz SSR), using paper chromatography in the petroleum ether-formamide and chloroform - formamide systems we have found not less than eight derivatives of benzo- $\alpha$-pyrone. The fact that these compounds belong to the coumarin group was established from the characteristic fluorescence of the spots in UV light before and after the treatment of the chromatograms with an ethanolic solution of alkali, by the azo-coupling reaction, and by the specific reaction with hydrochloric acid in liquid phenol [1].

In the petroleum ether-formamide system we found six coumarin derivatives in the roots investigated with $\mathbf{R}_{f} 0.15,0.20,0.28,0.31,0.67$, and 0.76 . In another system which is commonly used for the chromatography of polar coumarin compounds (chloroform-formamide) we found two other coumarins with a bright blue fluorescence having $\mathbf{R}_{f} 0.45$ and 0.55 .

The substances with $\mathrm{R}_{f} 0.15,0.45$, and 0.55 , which had $\mathrm{mps} 188-191^{\circ} \mathrm{C}, 234-235^{\circ} \mathrm{C}, 204-205^{\circ} \mathrm{C}$, were isolated preparatively by chromatography in a thin layer of alumina and on the basis of the absence of depression of the melting points of mixtures with the appropriate authentic samples and a comparison of the UV and $\mathrm{IR}$ spectra and $\mathrm{R}_{f}$ values in various systems they were identified as bergapten, umbelliferone, and scopoletin, respectively.

When the combined extracts from the roots of the plant under investigation were subjected to chromatographic separation on a column of alumina, the substance with $R_{f} 0.76$ (petroleum ether-formamide

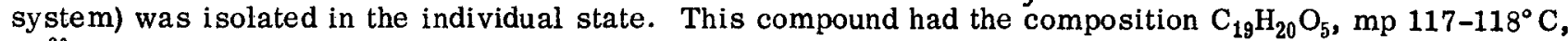
$[\alpha]_{\mathrm{D}}^{20}+289$ (c 0.3 ; ethanol); UV $\lambda_{\max } 326,250,260 \mathrm{~nm}(\log \varepsilon 3.87,3.33,3.31)$.

On the basis of a study of the products of alkaline hydrolysis and UV, IR, and NMR spectra, the compound investigated was identified as $\mathrm{O}$-trigloyl-4',5'-dihydrooroselol (zosimin, columbianadin), isolated previously from the fruit of Zosimia absinthifolia (Vent.), Link. [2], the roots of Lomatium columbianum Mathias et Constance $[3,4]$, the roots and fruit of Peucedanum palustre (L.) Moench. [5, 6], the fruit of $\mathbf{p}$. grande [7], the roots of Angelica laxiflora Diels. [8], the fruit of Heracleum ceylonicum Gardn., and the fruit and roots of $H$. sprengelianum Wight. et Arn. [9].

\section{LITERA TUR E CITED}

1. E. D. Georgobiani and N. F. Komissarenko, Soobshch. Akad. Nauk GruzSSR, 53, No. 2 (1969).

2. G. K. Nikonov and D. I. Baranauskaite, Zh. Obshch. Khim., 34, No. 11, 3854 (1964).

3. R. E. Willette and T. O. Soine, J. Pharm. Sci., 53, No. 3, 275 (1964).

4. T. O. Soine and K.-H. Lee, J. Pharm. Sci., 56, No. 5, 655 (1967).

5. B. E. Nielsen and J. Lemmich, Acta Chem. Scand., 18, No. 6, 1379 (1964).

6. B. E. Nielsen and J. Lemmich, Acta Chem. Scand., $\overline{19}$, No. 8, 1810 (1965).

7. S. A. Siddaqua and A. B. Sen, Lloydia, 35, No. 1, $84 \overline{(1972) .}$

8. K. Hata, M. Kozama, K. Baba, and Kun-Ying Yen, Chem. Pharm. Bull. (Tokyo), 19, No. 3, 640 (1971).

9. D. Mohlo, P. Jassang, and J. Carbonnier, Bull. Soc. Chim. Fr., No. 1, 208 (1972).

Khar'kov Scientific-Research Institute of Pharmaceutical Chemistry, M. V. Lomonosov Moscow University, Botanical Gardens. Translated from Khimiya Prirodnykh Soedinenii, No. 3, pp. 419-420, May-June, 1975. Original article submitted August 12, 1974.

(O)1976 Plenum Publishing Corporation, 227 West 17th Street, New York, N.Y. 10011. No part of this publication may be reproduced, stored in a retrieval system, or transmitted, in any form or by any means, electronic, mechanical, photocopying, microfilming, recording or otherwise, without written permission of the publisher. A copy of this article is available from the publisher for $\$ 15.00$. 